\title{
Immersion freezing of ice nucleation active protein complexes
}

\author{
S. Hartmann ${ }^{1}$, S. Augustin ${ }^{1}$, T. Clauss ${ }^{1}$, H. Wex ${ }^{1}$, T. Šantl-Temkiv ${ }^{2}$, J. Voigtländer ${ }^{1}$, D. Niedermeier ${ }^{1}$, and \\ F. Stratmann ${ }^{1}$ \\ ${ }^{1}$ Leibniz Institute for Tropospheric Research, Permoserstr. 15, 04318 Leipzig, Germany \\ ${ }^{2}$ Aarhus University, Stellar Astrophysics Centre, Department of Physics and Astronomy, 120 Ny Munkegade, \\ 8000 Aarhus, Denmark
}

Correspondence to: F. Stratmann (straddi@ tropos.de), S. Hartmann (hartmann@tropos.de)

Received: 25 July 2012 - Published in Atmos. Chem. Phys. Discuss.: 21 August 2012

Revised: 19 April 2013 - Accepted: 5 May 2013 - Published: 14 June 2013

\begin{abstract}
Utilising the Leipzig Aerosol Cloud Interaction Simulator (LACIS), the immersion freezing behaviour of droplet ensembles containing monodisperse particles, generated from a Snomax ${ }^{\mathrm{TM}}$ solution/suspension, was investigated. Thereto ice fractions were measured in the temperature range between $-5^{\circ} \mathrm{C}$ to $-38^{\circ} \mathrm{C}$. Snomax ${ }^{\mathrm{TM}}$ is an industrial product applied for artificial snow production and contains Pseudomonas syringae bacteria which have long been used as model organism for atmospheric relevant ice nucleation active (INA) bacteria. The ice nucleation activity of such bacteria is controlled by INA protein complexes in their outer membrane.

In our experiments, ice fractions increased steeply in the temperature range from about $-6^{\circ} \mathrm{C}$ to about $-10^{\circ} \mathrm{C}$ and then levelled off at ice fractions smaller than one. The plateau implies that not all examined droplets contained an INA protein complex. Assuming the INA protein complexes to be Poisson distributed over the investigated droplet populations, we developed the CHESS model (stoCHastic modEl of similar and poiSSon distributed ice nuclei) which allows for the calculation of ice fractions as function of temperature and time for a given nucleation rate. Matching calculated and measured ice fractions, we determined and parameterised the nucleation rate of INA protein complexes exhibiting class III ice nucleation behaviour. Utilising the CHESS model, together with the determined nucleation rate, we compared predictions from the model to experimental data from the literature and found good agreement.
\end{abstract}

We found that (a) the heterogeneous ice nucleation rate expression quantifying the ice nucleation behaviour of the INA protein complex is capable of describing the ice nucleation behaviour observed in various experiments for both,
Snomax ${ }^{\mathrm{TM}}$ and $P$. syringae bacteria, (b) the ice nucleation rate, and its temperature dependence, seem to be very similar regardless of whether the INA protein complexes inducing ice nucleation are attached to the outer membrane of intact bacteria or membrane fragments, (c) the temperature range in which heterogeneous droplet freezing occurs, and the fraction of droplets being able to freeze, both depend on the actual number of INA protein complexes present in the droplet ensemble, and (d) possible artifacts suspected to occur in connection with the drop freezing method, i.e., the method frequently used by biologist for quantifying ice nucleation behaviour, are of minor importance, at least for substances such as $P$. syringae, which induce freezing at comparably high temperatures. The last statement implies that for single ice nucleation entities such as INA protein complexes, it is the number of entities present in the droplet population, and the entities' nucleation rate, which control the freezing behaviour of the droplet population. Quantities such as ice active surface site density are not suitable in this context.

The results obtained in this study allow a different perspective on the quantification of the immersion freezing behaviour of bacterial ice nucleation.

\section{Introduction}

Ice formation in clouds influences the formation of precipitation and cloud radiative properties and therefore impacts both weather and climate (DeMott et al., 2003; Lohmann, 2006). Ice formation in clouds occurs either through homogeneous or heterogeneous ice nucleation. For the latter, an insoluble particle called ice nucleus lowers the energy barrier for the 
phase transition from liquid water to ice, causing freezing at higher temperatures than those observed in the case of homogeneous ice nucleation.

Atmospheric observations indicate that heterogeneous ice nucleation in mixed-phase clouds can already occur at temperatures higher than $-20^{\circ} \mathrm{C}$ (Ansmann et al., 2009; Seifert et al., 2010; Kanitz et al., 2011). In contrast, laboratory studies showed that the majority of non-biological substances found in atmospheric ice crystal residues, i.e., natural mineral dust (e.g., Twohy and Poellot, 2005; Pratt et al., 2009; Kamphus et al., 2010), are only ice active at lower temperatures (e.g., Hoose and Möhler, 2012; Murray et al., 2012). One possible explanation for the observed temperature differences might be the presence of biological material (e.g., bacteria) initiating freezing already at temperatures above $-10^{\circ} \mathrm{C}$. This biological material may be internally or externally mixed with other substances in atmospheric aerosol particles (Pratt et al., 2009).

Within the framework of this paper, we will focus on bacteria induced ice nucleation specifically considering the bacterial species Pseudomonas syringae. The importance of $P$. syringae for atmospheric ice nucleation was already suggested in the 1970s (Schnell and Vali, 1972). Maki et al. (1974) and Vali et al. (1976) related the ice nucleation activity of organic matter from decomposing plant leaves to the presence of this bacterial species. Besides $P$. syringae, other ice nucleation active (INA) bacteria species, such as Pseudomonas fluorescens, Pseudomonas viridiflava, Pantoea agglomerans or Xanthomas campestris, have been described. These INA bacteria can induce heterogeneous freezing at temperatures as high as $-1{ }^{\circ} \mathrm{C}$ (Morris et al., 2004) and are, therefore, among the most efficient ice nuclei (IN) known (e.g., Yankofsky et al., 1981; Levin and Yankofsky, 1983; Möhler et al., 2008). Most of the INA bacterial species typically grow on plant surfaces, where they cause massive frost damage at high subzero temperatures. In the 1980s, significant research on $P$. syringae and other INA bacteria was performed in the context of reducing frost damage on crops (Skirvin et al., 2000, gives an historical overview). Aside from residing on plant surfaces, $P$. syringae is commonly found on decaying plant material (Maki et al., 1974; van Overbeek et al., 2010; Monteil et al., 2012). Also soils harbouring dead plant material were suggested to represent a common environment for this INA bacterium (Monteil et al., 2012).

Due to natural (e.g., wind erosion) and anthropogenic (e.g, harvesting) processes, bacteria in general, and consequently also INA bacteria, can be dispersed into the atmosphere. Burrows et al. (2009) estimated that the mean bacterial concentrations in air over land are $>10^{4}$ cells per $\mathrm{m}^{3}$, which is in the range of total ice nuclei (IN) concentrations in the atmosphere $\left(10^{2}-10^{5}\right.$ per $\mathrm{m}^{3}$, Murray et al., 2012). Over agriculturally used areas, the number concentration of bacteria can

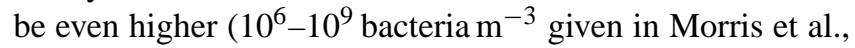
2004, and references therein), but the exact fraction of INA bacteria among all airborne bacteria remains poorly quantified. However, species belonging to Pseudomonas have often been found dominant among bacteria from fog and cloud water (Fuzzi et al., 1997; Amato et al., 2006; Ahern et al., 2007). Christner et al. (2008) reported that about $0.4 \%$ of bacterial cells in snowfall were ice nucleating active between $-4^{\circ} \mathrm{C}$ and $-7^{\circ} \mathrm{C}$. Morris et al. (2008) found that P. syringae was ubiquitously present in precipitation and freshwater and has suggested that INA bacteria are being disseminated as part of the water cycle. And most recently, DeLeon-Rodriguez et al. (2013) found that in particle samples from the middle to upper troposphere around $20 \%$ of the total particles in the diameter range from $250 \mathrm{~nm}$ to $1 \mu \mathrm{m}$ were viable bacterial cells, and based on that they claim that bacteria are an important and underestimated fraction of micrometer-sized atmospheric aerosol particles.

Concerning their ice nucleation ability, different INA bacteria may feature different behaviour. Even in the same population of $P$. syringae, Yankofsky et al. (1981) and later Turner et al. (1991) identified three different types/classes of bacteria. The most abundant one is class III, found in INA bacterial cells that nucleate ice in the range from about $-7^{\circ} \mathrm{C}$ to $-10^{\circ} \mathrm{C}$, and occurring in about " 1 of 300 cells" to "almost all cells" (Yankofsky et al., 1981; Turner et al., 1990). The class I and II bacterial IN are associated with bacterial cells which induce freezing already at temperatures around $-2{ }^{\circ} \mathrm{C}$ and $-5^{\circ} \mathrm{C}$. These two classes occur much more rarely, and different publications give numbers of 1 in $10^{3}$ to 1 in $10^{6}$ for classes II and I. (Yankofsky et al., 1981; Govindarajan and Lindow, 1988; Turner et al., 1990, 1991; Cochet and Widehem, 2000).

The ability of INA bacteria to nucleate ice is caused by a special protein anchored in the outer membrane of the bacterial cell wall (Wolber et al., 1986; Warren and Wolber, 1987). This INA protein is encoded by a single gene (Orser et al., 1985; Green and Warren, 1985), which is highly conserved among the INA bacterial species (Warren and Wolber, 1991). Thereby, different bacterial species and strains may feature different patterns of gene expression (for an overview see Després et al., 2012). The apparent molecular weight of an INA protein was estimated to be $120-180 \mathrm{kDa}$ (Kawahara, 2002) and its active surface area was given by Garnham et al. (2011) as $4 \mathrm{~nm} \times 32 \mathrm{~nm}$.

The INA proteins have been repeatedly shown to aggregate in bacterial outer membranes (e.g., Govindarajan and Lindow, 1988; Southworth et al., 1988; Mueller et al., 1990; Schmid et al., 1997). Govindarajan and Lindow (1988) estimated that two to more than a hundred proteins can be found in such an aggregate. Southworth et al. (1988) reported that INA proteins were found in groups of two to three. Through use of $\gamma$-radiation analysis, i.e., by gradually decreasing biological activity in a $P$. syringae sample, Govindarajan and Lindow (1988) derived that a single INA protein induces freezing at $-12^{\circ} \mathrm{C}$. Recently, Garnham et al. (2011) proposed that the INA proteins naturally form 
oligomers of at least two, i.e., dimers. It is concluded that oligomers consisting of two up to a few single proteins could correspond to class III IN, i.e., initiate freezing in the temperature range from about $-7^{\circ} \mathrm{C}$ to $-10^{\circ} \mathrm{C}$ (Govindarajan and Lindow, 1988; Garnham et al., 2011), where the majority of the INA bacteria can be ice nucleation active. Larger protein oligomers are considered to be active at higher temperatures and are thought to be related to class I and II bacterial IN (Schmid et al., 1997). Up to now, the structure and functionality of the INA protein oligomers has not been finally clarified and is still the object of contemporary research (Garnham et al., 2011).

Within the scope of this paper, we will adopt the concept of aggregates of INA proteins as the smallest ice nucleating entity and we will from here on call this entity INA protein complex as done in e.g., Morris and Sands (2012).

Next, we will deal with the state-of-the-art concerning bacterial ice nucleation experiments so far and the needs for further research. Following the drop freezing method as described in Vali (1971), since the 1970s, many studies investigated the ice nucleation behaviour of bacteria (e.g., Maki et al., 1974; Vali et al., 1976; Maki and Willoughby, 1978; Yankofsky et al., 1981; Lindow et al., 1982; Levin and Yankofsky, 1983; Orser et al., 1985; Turner et al., 1990; Cochet and Widehem, 2000). In most of these studies, the freezing of tens of droplets, which contained multiple $\left(10^{2}\right.$ to $10^{8}$ ) immersed bacteria cells per droplet and were placed on a substrate, was analysed and onset temperatures of freezing were determined. Such techniques feature two potential problems, i.e., (a) possible interferences by the substrate cannot be ruled out, and (b) the reported onset temperatures may not be the proper parameter for quantifying the ice nucleation behaviour. Concerning (a), in Murray et al. (2012) it is stated that "to date, relatively few experiments have examined the [ice] activity of bacteria using techniques validated to be free from potential interference such as nucleation by substrates". With respect to (b), from Niedermeier et al. (2011a), it can be concluded that both, the onset temperature of freezing, and the apparent temperature dependencies may be affected by the number of ice nuclei present in the freezing droplets. Such effects become obvious especially if the number of IN per droplet is large. Consequently, experiments should be carried out that examine the freezing of free-floating droplets, which contain only a small and defined number of bacteria and/or INA protein complexes. Such experiments are also closer to atmospheric conditions, under which more than one IN per droplet is rather unlikely.

Since 2000, some studies (e.g., Wood et al., 2002; Möhler et al., 2008) investigated the ice nucleation behaviour of air suspended droplets containing Snomax ${ }^{\mathrm{TM}}$ as a convenient surrogate for living bacteria. Snomax ${ }^{\mathrm{TM}}$ consists of nonviable $P$. syringae cells. However, in these studies, investigations were performed for polydisperse IN distributions, making the interpretation and quantification of the ice nucleation behaviour difficult, because polydisperse measurements usu- ally do not allow for the separation of size, composition and mixture (external vs. internal) effects.

Finally, almost all studies mentioned above used frozen droplet fractions and/or onset temperatures of freezing for quantifying the ice nucleation behaviour. This implies that the reported results could be experiment specific. In the present paper, we will use a different approach, i.e., the concept of temperature dependent nucleation rates for the quantification of the observed ice nucleation behaviour. We do so because (a) nucleation rate is not an experiment specific property, i.e., nucleation rates from different experiments can directly be compared, and (b) the concept of nucleation rates is consistent with the stochastic nature of the heterogeneous ice nucleation process (Niedermeier et al., 2011a).

Altogether, compared to former investigations, we use an admittedly more complicated, however, also more powerful technique for investigating bacterial ice nucleation behaviour. Our approach is free of potential interferences from substrates, allows for the consideration of a statistically relevant number of droplets, which contain only a small number of bacteria and/or bacteria fragments, includes particle size segregated measurements and therefore makes possible a more detailed investigation of bacterial ice nucleation behaviour.

Finally, we take a different perspective in quantifying the bacteria's ice nucleation behaviour, i.e., we are not looking at the number of bacteria, but the number of ice nucleation active protein complexes present in the investigated droplets and we use ice nucleation rates instead of onset temperatures and frozen fractions.

\section{Measurements}

\subsection{Snomax $^{\mathrm{TM}}$ and particle generation}

Particles examined in our study were produced from Snomax $^{\mathrm{TM}}$ (Johnson Controls Snow, Colorado, USA). Snomax ${ }^{\mathrm{TM}}$ consists of pellets that contain non-viable Pseudomonas syringae bacteria, their fragments, i.e., cell constituents and fragments of the cell membrane with or without attached INA protein complex, remnants of the nutrition medium used for bacterial cultivation, and some other unknown byproducts. Usually, Snomax ${ }^{\mathrm{TM}}$ is applied for artificial snow production purposes. However, as it contains $P$. syringae bacteria, which have long been used as a model organism for atmospheric relevant INA bacteria, we utilise Snomax ${ }^{\mathrm{TM}}$ as a convenient source for these bacteria, or better, for providing INA protein complexes as occurring on $P$. syrinage and other INA bacteria.

Particle generation for our study was carried out using conventional particle generation technology for the production of particles from liquids. In a first step, $1.6 \mathrm{~g}$ Snomax ${ }^{\mathrm{TM}}$ pellets were dissolved/suspended in $1 \mathrm{~L}$ double deionized water. An atomizer (design similar to TSI 3076) was used to spray 
the solution/suspension (Fig. 1). The generated droplets were dried in a diffusion dryer, and dry particles were provided for further analysis. The resulting number size distribution, as measured using a Differential Mobility Analyser (DMA, type "Vienna medium", Knutson and Whitby, 1975) together with a Condensation Particle Counter (CPC, TSI 3010, TSI Inc., St. Paul, Minnesota, USA) is shown in Fig. 6 (red curve). As can be seen, particles are distributed over the entire diameter range $(20 \mathrm{~nm}$ to $800 \mathrm{~nm})$ examined. This indicates that not only intact bacteria cells are present in the generated aerosol. Intact bacteria cells appear in the size range around $800 \mathrm{~nm}$, visible as small bump in the size distribution. This is consistent with the size range in which bacteria cells for Snomax ${ }^{\mathrm{TM}}$ and $P$. syringae were found in Möhler et al. (2008). The generated particles at sizes below the small bump are not made up of intact bacteria, but contain other Snomax ${ }^{\mathrm{TM}}$ ingredients such as e.g., cell constituents and nutrition remnants and also, as will later follow from our results, fragments of cell membrane with intact INA protein complexes. It should be noted that there is a possibility that during particle generation bacterial cells are destroyed and/or INA protein complexes may lose their ice nucleation ability. However, this will not affect our results, as we are interested in quantifying the ice nucleation ability of the smallest INA entity, which in our view is the intact INA protein complex, regardless of whether it is attached to an intact cell or a cell membrane fragment. The applicability of the gained results to intact non-viable and viable $P$. syringae bacteria will be discussed below.

In the course of our ice nucleation experiments, sizesegregated particles were used. The DMA was used for size selection and the CPC for monitoring the number concentration of the particles provided for the measurements.

\subsection{LACIS}

LACIS (Leipzig Aerosol Cloud Interaction Simulator, Stratmann et al., 2004) is a multi-purpose instrument for investigating aerosol cloud interactions and cloud microphysical processes such as aerosol particle hygroscopic growth, cloud droplet activation, growth and freezing. In the framework of the present paper, it is used for investigating the immersion freezing behaviour of well-characterised, size-selected particles generated from a Snomax ${ }^{\mathrm{TM}}$ solution/suspension as a function of temperature with only one particle immersed in each droplet. In this section, the setup and operating principle will be described briefly, especially with respect to technical innovations, compared to former experiments as described in Niedermeier et al. (2010, 2011b) and Hartmann et al. (2011).

The schematic setup of the particle generation, the LACIS flow tube, and the optical detection system are shown in Fig. 1. Particles were generated as described above and then fed into LACIS. Additionally, a particle free sheath air flow was conditioned with respect to its humidity by mixing a dry and a humidified (humidifier, PH-30T-24KS, Perma Pur, Toms River, New Jersey) air flow prior to entering the

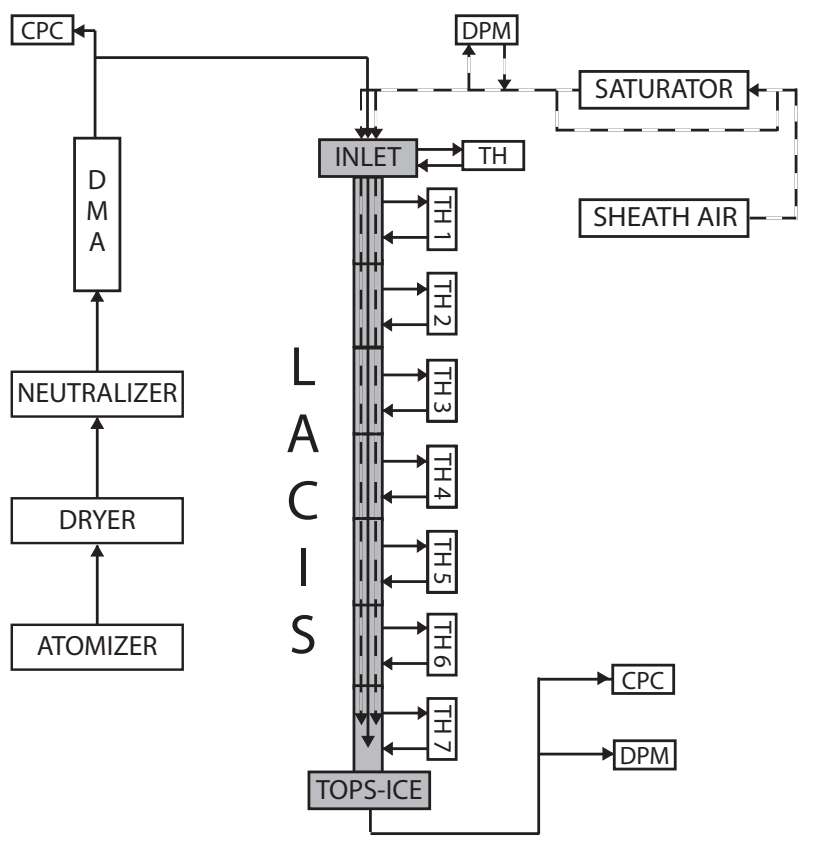

Fig. 1. Setup of the particle generation, the LACIS flow tube and optical detection system. The abbreviations stand for: DMA - Differential Mobility Analyser, DPM - chilled mirror dew point hygrometer, TH - thermostat, TOPS-Ice - Thermally Stabilized Optical Particle Spectrometer, and CPC - condensational particle counter.

flow tube. A chilled mirror dew point hygrometer (DPM, DPM 973, MBW Calibration Ltd., Wettingen, Switzerland) was used to monitor the dew point of the sheath air flow. The aerosol and sheath air flows were combined in the inlet section of LACIS, which serves as heat exchanger for harmonizing the inlet temperatures of both air flows. The sheath air enters the laminar flow tube isokinetically with the aerosol flow, with the latter forming an aerosol beam with a diameter of roughly $2 \mathrm{~mm}$ in the centre of the flow tube. The flow tube consists of seven connected one-metre tube sections with an inner diameter of $15 \mathrm{~mm}$. The wall temperature of each tube section is set separately by different thermostats (TH).

At the outlet of LACIS, the self-build Thermally Stabilized Optical Particle Spectrometer (TOPS-Ice, Clauss et al., 2013) is used to determine number and phase state of the hydrometeors exiting LACIS. The phase state discrimination takes place via the evaluation of the polarization state of scattered light in $42.5^{\circ}$ forward direction. By use of TOPS-Ice, we obtain ice fractions, i.e., the number of frozen droplets divided by the total number of hydrometeors (unfrozen droplets and ice particles), together with droplet sizes. At the outlet of LACIS, a CPC and a DPM are installed for monitoring purposes only.

For investigating the immersion freezing behaviour of biological particles, temperatures ranging from $0{ }^{\circ} \mathrm{C}$ to $-35^{\circ} \mathrm{C}$ were considered. This is an innovation compared to older studies (Niedermeier et al., 2010, 2011b; Hartmann et al., 

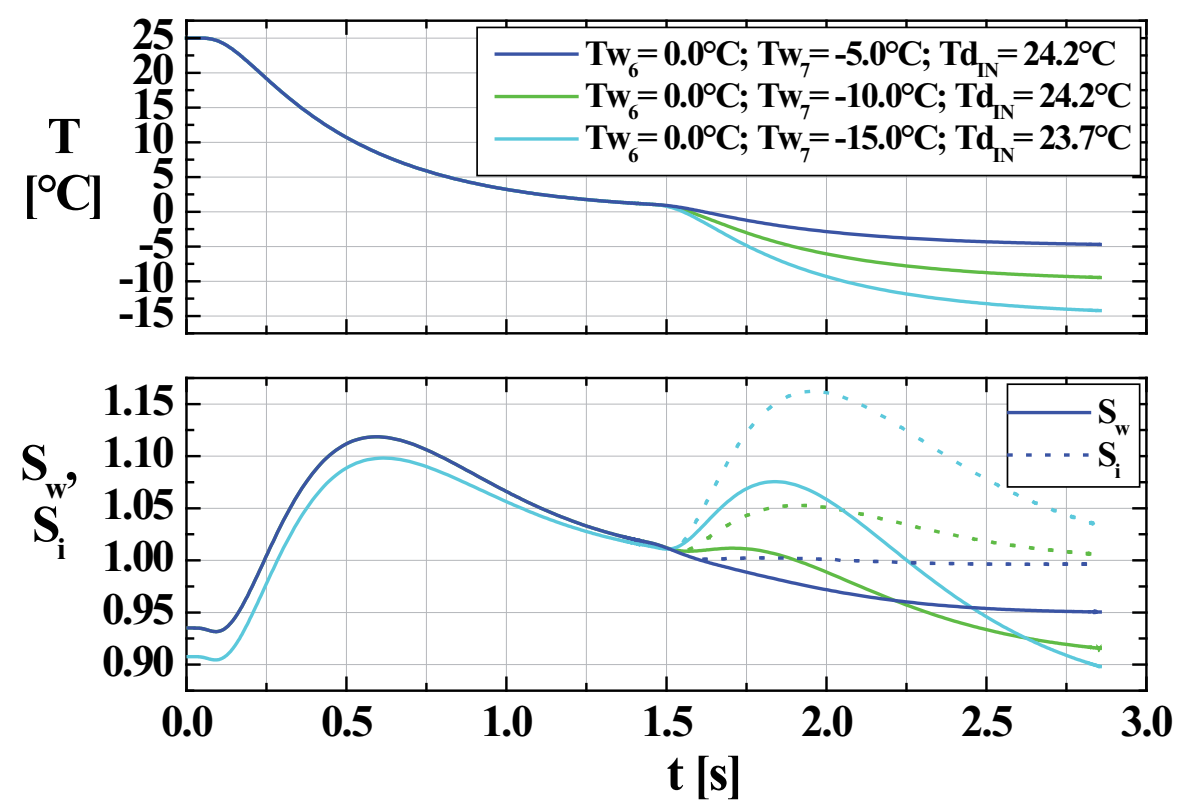

Fig. 2. Temperature $T$ (upper panel) and saturation with respect to liquid water $S_{\mathrm{W}}$ (solid lines, lower panel) and ice $S_{\mathrm{i}}$ (dotted lines, lower panel) at the centerline of LACIS as function of residence time $t$ in Sect. 6 and 7 for different boundary conditions (wall temperature $T_{\mathrm{W}}$ and inlet dew point temperature $\left.T_{\mathrm{d}, \mathrm{IN}}\right)$.

2011) in which only the temperature range between $-26^{\circ} \mathrm{C}$ and $-40^{\circ} \mathrm{C}$ was covered. Furthermore, taking advantage of TOPS-Ice's ability to distinguish the phase states of the hydrometeors leaving LACIS, and in contrast to former investigations, LACIS was run such that both droplets and ice particles were present at its outlet.

The following LACIS parameters were used for the experiments performed in the temperature range between $0^{\circ}$ and $-25^{\circ} \mathrm{C}$ : the inlet as well as the wall temperatures of sections 1 to 5 were set to $25.0^{\circ} \mathrm{C}$, the inlet dew point temperature was varied in a range from $23.7^{\circ} \mathrm{C}$ to $24.2^{\circ} \mathrm{C}$. The inner tube wall of sect. 6 was covered with liquid water and had a temperature of $0^{\circ} \mathrm{C}$. The wall temperature of sect. 7 was set to the temperature of interest ranging from $0{ }^{\circ} \mathrm{C}$ to $-25^{\circ} \mathrm{C}$, and the inner tube wall was covered with ice.

To outline the thermodynamical conditions prevailing inside LACIS under such boundary conditions, Fig. 2 depicts modelled temperature (upper panel) and saturation with respect to water and ice (lower panel) at the centerline of sect. 6 and 7 , exemplarily for wall temperatures of $-5^{\circ} \mathrm{C},-10^{\circ} \mathrm{C}$, and $-15^{\circ} \mathrm{C}$ (obtained with the combined Fluent/FPM model, Fluent: ANSYS Inc., Canonsburg, PA, USA, FPM: Particle Dynamics GmbH, Leipzig, Germany, Wilck et al., 2002).

The temperature profiles show a steep decrease in sect. 6 , approaching the wall temperature of $0{ }^{\circ} \mathrm{C}$ at the end of the section. In sect. 7, due to the lower wall temperature, the temperature decreases further. At the end of sect. 7, the temperature at the centerline matches the wall temperatures with a deviation of $0.30 \mathrm{~K}$ for $-5.00^{\circ} \mathrm{C}$, of $0.53 \mathrm{~K}$ for $-10.00^{\circ} \mathrm{C}$, and of $0.76 \mathrm{~K}$ for $-15.00^{\circ} \mathrm{C}$. These temperature deviations are accounted for in the data evaluation. In other words, results are reported in terms of centerline temperatures.

As can be seen in the lower panel of Fig. 2, the saturation with respect to water rises very steeply in sect. 6 , reaches its maximum, and then decreases approaching water saturation at the end of sect. 6. As soon as the critical super-saturation is reached, the particles are activated to droplets and these droplets grow dynamically to sizes of about $4 \mu \mathrm{m}$ at the end of sect. 6 , depending on the prevailing saturation. The water saturation decreases further for a wall temperature of $-5^{\circ} \mathrm{C}$. For wall temperatures of $-10{ }^{\circ} \mathrm{C}$ and $-15^{\circ} \mathrm{C}$, the saturation with respect to water increases again at the beginning of sect. 7. This leads to further droplet growth. For all settings, the water-saturation then decreases below 1 , while the saturation with respect to ice approaches 1 . Consequently, droplets evaporate slightly in the prevailing ice super-saturated and water sub-saturated environment. It should be noted that all experiments were carried out for similar droplet diameters $(2.5 \pm 0.5 \mu \mathrm{m})$ at the end of sect. 7. Therefore, the inlet dew point temperature, as second parameter for controlling droplet size, was adjusted accordingly.

In addition to the measurements performed in the temperature range between $0{ }^{\circ} \mathrm{C}$ to $-25^{\circ} \mathrm{C}$, experiments were also carried out at lower temperatures (ranging from $-26^{\circ} \mathrm{C}$ to $-38^{\circ} \mathrm{C}$ ), following the operation mode described in Hartmann et al. (2011), however, with higher inlet dew point temperatures to ensure that both droplets and ice particles pass through the outlet of LACIS. 


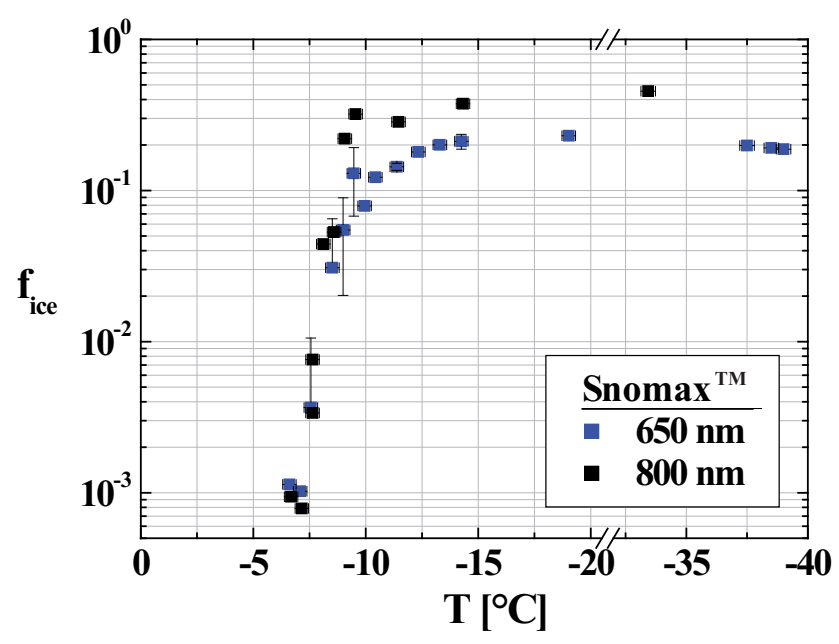

Fig. 3. Ice fraction $f_{\text {ice }}$ as function of temperature $T$ for $650 \mathrm{~nm}$ and $800 \mathrm{~nm}$ particles generated from a Snomax ${ }^{\mathrm{TM}}$ solution/suspension.

\section{Results and discussion}

\subsection{Experimental results}

The immersion freezing behaviour of size-selected particles (mobility diameter $D_{\mathrm{P}}: 100 \mathrm{~nm}, 300 \mathrm{~nm}, 400 \mathrm{~nm}$, $650 \mathrm{~nm}$, and $800 \mathrm{~nm}$ ) generated from a Snomax ${ }^{\mathrm{TM}}$ suspension/solution was studied. For $650 \mathrm{~nm}$ and $800 \mathrm{~nm}$ particles, the ice fraction $f_{\text {ice }}$ was analysed as a function of temperature in the range from $-6.6^{\circ} \mathrm{C}$ to $-38^{\circ} \mathrm{C}$. The results are shown in Fig. 3. The ice fraction curves are very steep, almost linear for temperatures between $-6.6{ }^{\circ} \mathrm{C}$ and $-9.5^{\circ} \mathrm{C}$. The respective measurement uncertainties are represented by single standard deviations determined from at least 3 independent measurements performed under identical conditions.

As can be seen, for $T \leq-15^{\circ} \mathrm{C}$, the ice fraction curves level off to constant values of about 0.2 and 0.4 for the $650 \mathrm{~nm}$ and $800 \mathrm{~nm}$ particles, respectively. As the ice fractions do not increase any further, we conclude that a saturation regime is reached, i.e., there are no further IN present in the droplet population which can initiate freezing even at the low temperatures considered. This suggests that only $20 \%$ of $650 \mathrm{~nm}$ and $40 \%$ of $800 \mathrm{~nm}$ particles generated from Snomax ${ }^{\mathrm{TM}}$ solution/suspension are ice active. As described in the Introduction, the ice nucleation ability of Snomax ${ }^{\mathrm{TM}}$ or better the $P$. syringae is due to INA protein complexes attached to the bacterias' outer cell membrane or fragments of cell membrane. Consequently, our results imply that only $20 \%$ of the $650 \mathrm{~nm}$ and $40 \%$ of the $800 \mathrm{~nm}$ particles generated from Snomax ${ }^{\mathrm{TM}}$ solution/suspension contain one or more INA protein complexes, and that the unfrozen droplets do not even contain a single INA protein complex.

Before looking into the data in more detail, it should be clarified to which class (I, II, or III) of ice nucleation ac- tivity, observed for $P$. syringae, the majority of INA protein complexes observed in our experiments belong. For the performed experiments, droplets contained no or only a very small number of INA protein complexes. Between 1000 to 10000 frozen droplets, i.e., droplets containing INA protein complexes, were counted for determining an ice fraction. Considering the respective probabilities given in the Introduction ( 1 in $10^{3}$ to 1 in $10^{6}$ for class II and I), it is unlikely that significant and detectable numbers of class I and II proteins are present in the droplets. Additionally, (a) the logarithm of $f_{\text {ice }}$ increases linearly in the temperature range from $-6.6^{\circ} \mathrm{C}$ to $-9.5^{\circ} \mathrm{C}$, suggesting that only one class of IN is present, and (b) freezing occurs in a temperature range similar to that reported by Yankofsky et al. (1981) and Turner et al. (1991) for class III ice nucleation activity. This suggests that we observed class III bacterial ice nucleation activity in our experiments, which, according to literature (see Introduction) corresponds to protein complexes consisting of two up to a few single proteins.

Having identified the ice nucleation activity class, we now return to the measured ice fractions, their saturation behaviour, and the resulting consequences. The left panel of Fig. 4 shows ice fractions in the saturation range, denoted as $f_{\text {ice }}^{\star}$ and measured at about $-15^{\circ} \mathrm{C}$, as a function of the size of the particles fed into LACIS. For $100 \mathrm{~nm}$ particles we observe almost no freezing. In general, $f_{\text {ice }}^{\star}$, and consequently the number of INA protein complexes present in the particles, increases with increasing mobility diameter $D_{\mathrm{P}}$, but not in a linear manner. As mentioned before, not all droplets contain an INA protein complex, and it can be seen in Fig. 4 that the number of protein complexes present in a droplet is related to particle size. This offers the possibilities to determine the average number of INA protein complexes distributed over the droplet ensemble for each specific experiment (i.e., for each of the examined particle sizes), and also the determination of the IN size distribution underlaying the particle size distribution resulting from atomization of the Snomax ${ }^{\mathrm{TM}}$ suspension/solution. These topics will be dealt with next.

\subsection{Distribution of INA protein complexes over droplet ensembles and IN size distribution}

As not all droplets contain an INA protein complex, the number of INA protein complexes distributed over the droplet ensemble is small compared to the number of droplets forming the population. Consequentely, it can be assumed that the INA protein complexes are Poisson distributed over the droplet population (a similar approach can be found for other ice nucleating components in Vali, 1971; Yankofsky et al., 1981). The probability that a droplet contains $k$ INA protein complexes $(k$ varies in the range of $k=0, \ldots, n)$ is then given by

$P_{\lambda}(X=k)=\frac{\lambda^{k}}{k !} \exp (-\lambda)$, 

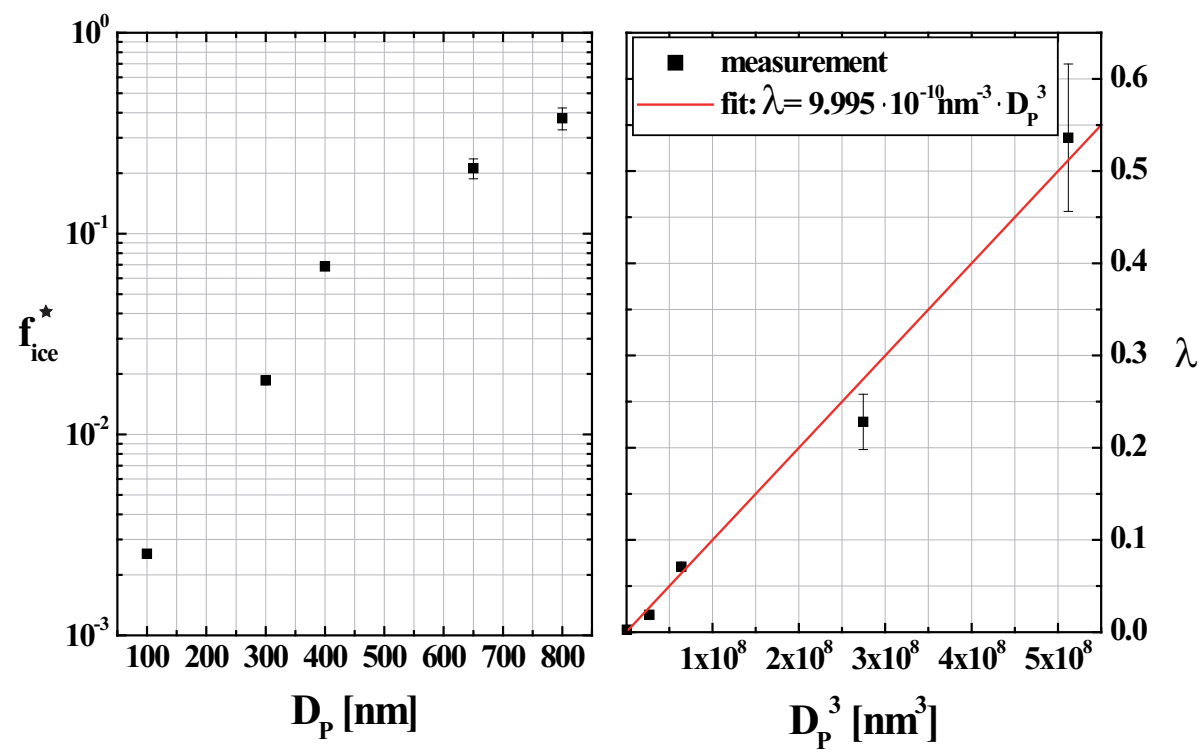

Fig. 4. Ice fraction $f_{\text {ice }}^{\star}$ vs. mobility diameter $D_{\mathrm{p}}$ (left panel) at $T=-15^{\circ} \mathrm{C}$ (saturation range). Measured $\lambda$ and fit function describing the average number of INA protein complexes per particle generated from a Snomax ${ }^{\mathrm{TM}}$ solution/suspension, as function of particle volume $\left(D_{\mathrm{P}}^{3}\right)$ (right panel).

with parameter $\lambda$, the average number of INA protein complexes per droplet. The measured ice fraction $f_{\text {ice }}$, and consequently also $f_{\text {ice }}^{\star}$, correspond to the probability of freezing. Assuming that a droplet can only freeze if it contains at least one INA protein complex, or the other way around that it does not freeze if it does not contain an INA protein complex, the probability that a droplet does not contain an INA protein complex can be written as

$P(X=0)=\exp (-\lambda)=1-f_{\text {ice }}^{\star}$

and consequently,

$\lambda=-\ln \left(1-f_{\text {ice }}^{\star}\right)$.

This equation offers the possibility of determining $\lambda$, the expected value for the number of INA protein complexes per droplet, from the experimentally determined ice fractions in the saturation range $f_{\text {ice }}^{\star}$. Equation (3) is defined only for $f_{\text {ice }}^{\star}<1$, i.e., in other cases $\lambda$ cannot be unambiguously determined.

As each droplet is grown on a single particle generated from the Snomax ${ }^{\mathrm{TM}}$ suspension/solution, and as during each measurement all droplets contain particles of the same size, the parameter $\lambda$ corresponds also to the expected number of INA protein complexes per particle fed into LACIS. Consequently, $\lambda$ can be related to particle size. The right panel of Fig. 4 shows $\lambda$ values as a function of $D_{\mathrm{P}}^{3}$, i.e., particle volume. As can be seen, $\lambda$ is a linear function of $D_{\mathrm{P}}^{3}$, illustrated by the linear fit (red line). This volume dependence of $\lambda$ can be explained as follows. The number of INA protein complexes in the atomized solution/suspension is proportional to the mass of Snomax ${ }^{\mathrm{TM}}$ used for producing the solution/suspension. Assuming that no demixing takes place during atomization of the solution/suspension, the number of INA protein complexes per generated particle is proportional to the particle mass. Furthermore, assuming that in course of the droplet activation process inside LACIS all INA protein complexes become accessible (i.e., the soluble particle fraction dissolves completely), a mass, and considering a size independent particle density, a particle volume dependence of the average number of INA protein complexes per particle is expected. In this context it should be mentioned that the number of INA protein complexes per particle volume or mass is a fundamentally different property compared to, for example, active site density (DeMott, 1995). While active site density associates ice nucleating sites to a particle surface area, the number of INA complexes relates ice nucleation ability to the number of complexes present, regardless whether they are attached to a particle surface or not. In general one could image active site surface density being a suitable property for characterising insoluble ice nuclei such as dust particles, while number of INA entities is better suited for e.g., soluble particles containing small ice nucleating entities such as INA protein complexes.

Knowing $\lambda$ as a function of particle volume, the distribution of INA protein complexes over a monodisperse particle population can be calculated by means of Eq. (1). The respective results are shown in Fig. 5, depicting the probability of $k$ INA protein complexes occurring in particles of different sizes. Considering a population of $100 \mathrm{~nm}$ particles, the majority of particles contain no INA protein complex $(k=0)$, and only a very small fraction of $10^{-3}$ includes one protein 


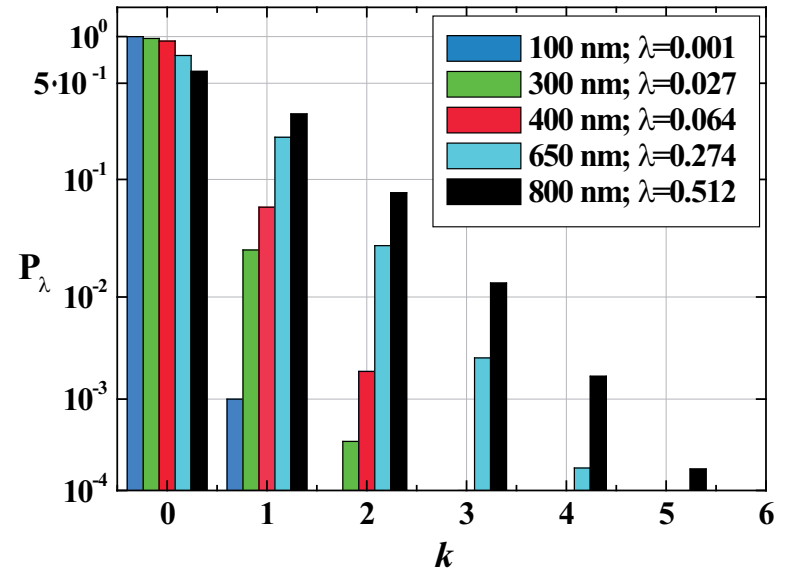

Fig. 5. Probability $P_{\lambda}$ for $k=0,1,2,3,4,5$ INA protein complexes per particle/droplet (Poisson distributed) for different average numbers of INA protein complexes $\lambda$.

complex $(k=1)$. For $300 \mathrm{~nm}$ particles, the fraction of particles containing one INA protein complex is higher, and furthermore, a minor fraction of particles has two INA protein complexes. For a particle diameter of $800 \mathrm{~nm}, 40 \%$ of all particles contain basically either 1, 2, 3, 4 or 5 INA protein complexes. With this, the IN number size distribution $n_{\mathrm{IN}}$ can be determined from the number size distribution of the particles generated from the Snomax ${ }^{\mathrm{TM}}$ suspension/solution $n_{0}$ :

$n_{\mathrm{IN}}=\left(1-\exp \left(-\lambda\left(D_{\mathrm{P}}^{3}\right)\right) n_{0}\right.$.

This is illustrated in Fig. 6. This Figure shows clearly that the majority of the particles do not contain an INA protein complex, and therefore do not function as ice nuclei, whereby the fraction of particles with IN to those without IN increases with increasing particle diameter. However, the presence of IN in the size range of a few $100 \mathrm{~nm}$ also shows that fragments of bacterial cell membrane with intact INA protein complexes are present.

The IN number size distribution shown in Fig. 6 is in contradiction to Möhler et al. (2008) who speculated, based on polydisperse measurements, that only particles in the larger mode $\left(D_{\mathrm{P}} \geq 600 \mathrm{~nm}\right)$ of the bimodal size distribution are ice active. Results obtained in the study by Wood et al. (2002) support our finding of INA protein complexes being present also in smaller size classes. They analysed a filtered Snomax ${ }^{\mathrm{TM}}$ solution/suspension containing only particles with diameters smaller than $200 \mathrm{~nm}$ and observed immersion freezing.

For particles in the size range around $800 \mathrm{~nm}$, where we expect to find the intact $P$. syringae cells, less than $50 \%$ of the particles functioned as ice nuclei. Under the assumption that all particles in this size range are intact bacteria cells, this would imply that although the $P$. syringae contained in

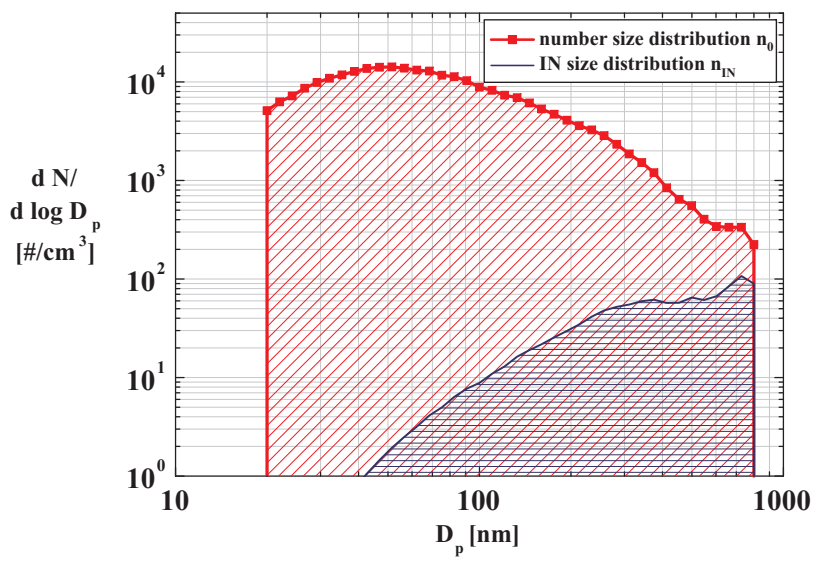

Fig. 6. Number size distribution of particles generated from a Snomax ${ }^{\mathrm{TM}}$ solution/suspension $n_{0}$ and derived IN size distribution $n_{\text {IN }}$

Snomax ${ }^{\mathrm{TM}}$ are grown under idealized conditions to maximize their ice nucleation ability, apparently less than every other bacterium induces ice nucleation.

Knowing the IN number size distribution, the ice fraction to be expected in an immersion freezing experiment considering a polydisperse particle population, can be derived by dividing the integral over the IN size distribution by the integral over the particle size distribution. For the distributions shown in Fig. 6, we calculate an expected ice fraction of $0.4 \%$ at $T=-15{ }^{\circ} \mathrm{C}$. This agrees well with the result of a polydisperse measurement performed at LACIS at $T=-15^{\circ} \mathrm{C}$, which yielded an ice fraction of $0.55 \%$. The slightly higher measured value can be explained by the fact that for the prediction only particle sizes up to $800 \mathrm{~nm}$ could be considered, while it is likely that during the experiment some particles with sizes larger than $800 \mathrm{~nm}$ (probably up to about $1300 \mathrm{~nm}$ ) were present.

Up to here, we determined the average/expected number of INA protein complexes per particle. As each droplet in LACIS contains only a single particle, the average/expected number of INA protein complexes per particle is equal to the average/expected number of complexes per droplet. Knowing the average/expected number of INA protein complexes per droplet, we can now deal with the quantification of the ice nucleation behaviour of the INA protein complexes.

\subsection{Determination of nucleation rate}

Knowing the number of $P$. syringae's class III INA protein complexes per particle/droplet, we quantify their ice nucleation behaviour in terms of a temperature dependent heterogeneous ice nucleation rate. Thereto, combining the assumptions that (a) heterogeneous ice nucleation is a stochastic process (Niedermeier et al., 2011a), and (b) the distribution 
of INA protein complexes over the droplet population can be described by a Poisson distribution, we developed the CHESS model (stoCHastic modEl of similar and poiSSon distributed ice nuclei). The CHESS model, at this stage, should be considered a tool for quantifying the nucleation rate of the INA protein complexes based on the ice fractions measured at LACIS. In the model, it is assumed that all INA protein complexes are similar and that only the INA protein complexes initiate droplet freezing. Hence, the probability of freezing of a droplet containing one INA protein complex $p_{1}$ at temperature $T$ can be described as:

$p_{1}=1-\exp \left(-S_{\text {site }} j_{\text {het }}(T) t\right)$

with the surface area of an INA protein complex $S_{\text {site, }}$, the temperature dependent heterogeneous ice nucleation rate coefficient $j_{\text {het }}$, and the ice nucleation time $t$. If a droplet possesses $k>1$ immersed INA protein complexes, the probability of freezing is increased due to an increased ice nucleation active surface area $k S_{\text {site }}$. Following the assumption that all INA protein complexes have similar properties, and hence similar surface areas, the probability of freezing of a droplet containing $k$ INA protein complexes is given by:

$p_{k}=1-\exp \left(-k S_{\text {site }} j_{\text {het }}(T) t\right)$

Considering, as a next step, a droplet ensemble at a certain temperature, and containing Poisson distributed INA protein complexes, the probability of droplet freezing is determined by the product of the probability that a droplet contains at least one INA protein complex $P_{\lambda}(k \geq 1)$ and the probability $p_{k}$ that one of this INA protein complexes induces freezing:

$f_{\text {ice }}(T)=\sum_{k=1}^{n} p_{k} P_{\lambda}(X=k)$.

Inserting Eq. (1) and Eq. (6), after several conversion steps, we obtain the expression:

$$
f_{\text {ice }}(T)=1-\exp \left(-\lambda\left(1-\exp \left(-S_{\text {site }} j_{\text {het }}(T) t\right)\right)\right) .
$$

It should be noted that $f_{\text {ice }}$ corresponds to the probability that one droplet out of a population freezes at temperature $T$ after time $t$, where the population contains on average $\lambda$ INA protein complexes, with each complex featuring an ice nucleation active surface $S_{\text {site }}$, and a temperature dependent heterogeneous ice nucleation rate coefficient $j_{\text {het }}(T)$.

All quantities of Eq. (8) are known except for $S_{\text {site }}$ and $j_{\text {het }}$. Consequently, the product of these quantities, which corresponds to the heterogeneous ice nucleation rate $J_{\text {het }}(T)=$ $S_{\text {site }} j_{\text {het }}(T)$ with the unit \# $\mathrm{s}^{-1}$, can be derived from the ice fractions measured at LACIS, for a given ice nucleation time. The ice nucleation time $t$ used for the determination of $J_{\text {het }}$ is defined as time period in which the temperature at the centerline of LACIS is in the range of $T_{\text {end }}+0.3 \mathrm{~K} \geq T \geq T_{\text {end }}$,

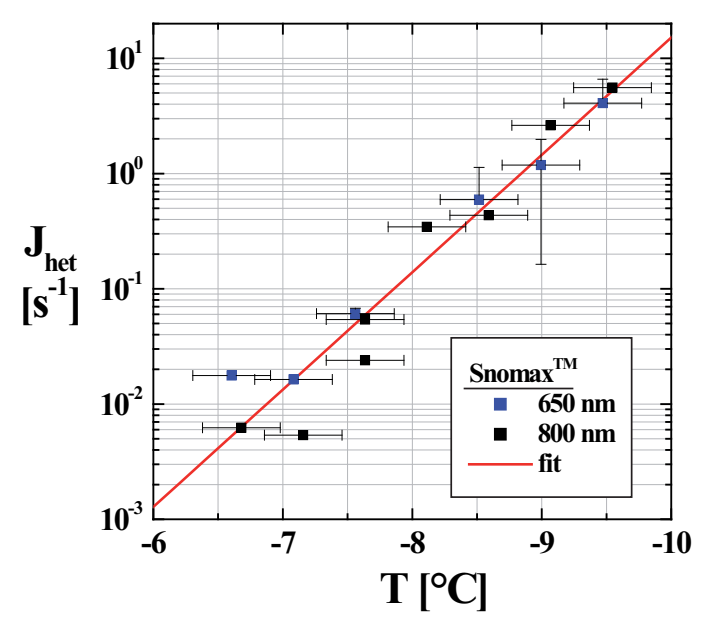

Fig. 7. Heterogeneous ice nucleation rate of single INA protein complexes $J_{\text {het }}$ as function of temperature $T$ derived for $650 \mathrm{~nm}$ and $800 \mathrm{~nm}$ particles.

whereby $T_{\text {end }}$ corresponds to the temperature at the centerline at the outlet of LACIS. $J_{\text {het }}$ should therefore be considered as the average nucleation rate in the temperature interval $T_{\text {end }}+0.3 \mathrm{~K}$ to $T_{\text {end }}$. The results gained for $650 \mathrm{~nm}$ and $800 \mathrm{~nm}$ particles are shown in Fig. 7. Here, we only use the range in which the logarithms of the ice fractions increase linearly with temperature $\left(-6.6{ }^{\circ} \mathrm{C} \geq T \geq-9.5^{\circ} \mathrm{C}\right)$, i.e., well outside the temperature range in which the ice fractions become saturated. $J_{\text {het }}$ derived for both, $650 \mathrm{~nm}$ and $800 \mathrm{~nm}$ sized particles fall together within the level of uncertainty. In other words, the nucleation rate is not a function of initial particle size or number of INA protein complexes present in the droplets. This is expected and confirms that we are indeed determining the nucleation rates of single INA protein complexes.

Next, we parameterise the ice nucleation rate $J_{\text {het }}$ as a function of temperature:

$J_{\text {het }}(T)=S_{\text {site }} j_{\text {het }}(T)=A \exp (B T)$.

with the coefficients $A=9.99 \times 10^{-10} \mathrm{~s}^{-1}$ and $B=$ $-2.34^{\circ} \mathrm{C}^{-1}$ being valid for $P$. syringae's class III INA protein complexes (red line in Fig. 6).

In the experiments, temperatures in the nucleation zone vary by $0.3 \mathrm{~K}$. The above derived $J_{\text {het }}$, however, was derived for the centerline temperature at the LACIS outlet. Model simulations with Fluent/FPM were carried out in which we accounted for this temperature variation of $0.3 \mathrm{~K}$. According to these simulations, coefficient $B$ is not affected and differences in coefficient $A$ are less than $10 \%$. These differences are well within the measurement uncertainty and hence the assumption of a constant temperature in the nucleation zone is feasible.

Comparing the temperature dependence of the derived heterogeneous ice nucleation rate parameterisation (Eq. 9) 

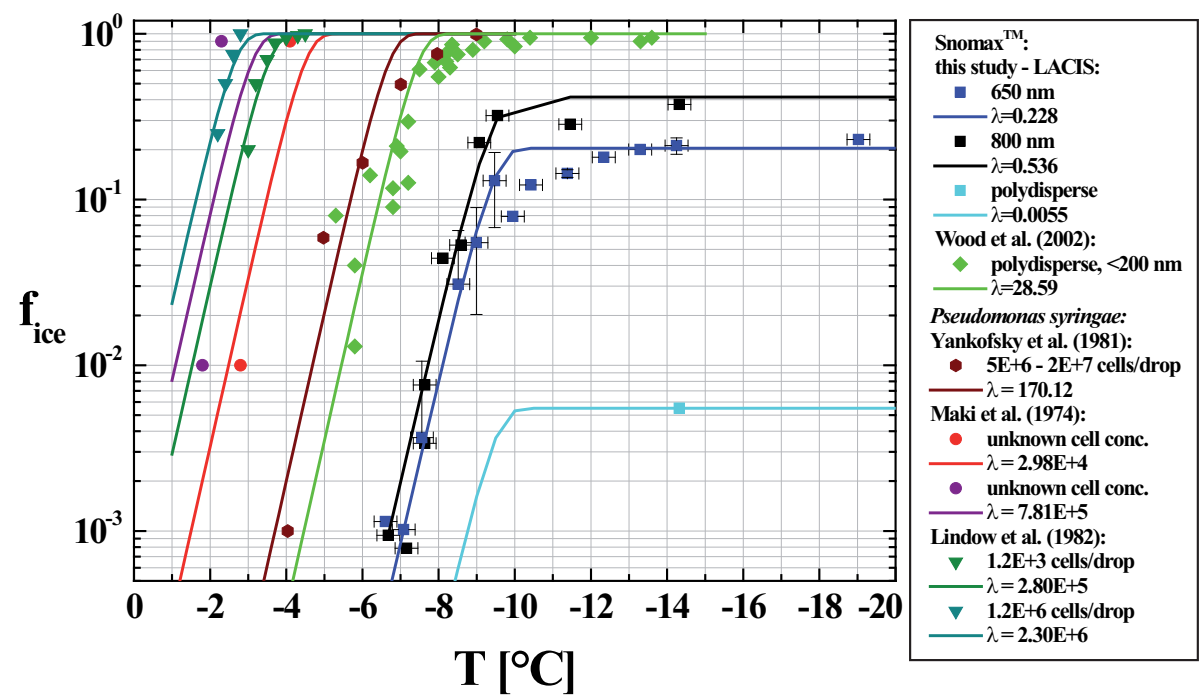

Fig. 8. A comparison of measured and calculated ice fractions obtained from the CHESS model with data from literature, see legend. Measured (data points) and calculated (lines) ice fractions $f_{\text {ice }}$ are given as function of temperature $T$.

with that determined applying Classical Nucleation Theory (CNT) using only one contact angle (not shown here), we found slightly less pronounced temperature dependence for the parameterised nucleation rate. From Niedermeier et al. (2011a) it can be concluded that this is most likely due to the investigated INA protein complexes not having fully identical properties. This heterogeneity of the INA protein complexes could imply both, variations in size and/or structure. In other words, although we are investigating the ice nucleation behaviour of single INA protein complexes, that does not necessarily imply that all INA protein complexes are fully identical. Therefore, the given parameterisation for the nucleation rate has to be considered as the average rate for the class III INA protein complexes. A higher level, and more accurate, parameterisation could be developed based on the Soccer ball model, and the assumption of a contact angle distribution (Niedermeier et al., 2011a). However, this goes beyond the scope of the present paper and is left for future investigations.

In summary, based on measured ice fractions, and utilising the newly developed CHESS model, we were able to quantify the ice nucleation behaviour of the INA protein complex which controls the ice nucleation ability of $P$. syringae. As result we provide ice nucleation rates as a function of temperature.

\subsection{Application of the nucleation rate to experimental data}

We will now investigate the applicability of the determined nucleation rate, and thereto we will try to reproduce results from different experiments reported in literature, using the CHESS model (Eq. 8). We implemented the above derived parameterisation for the INA protein complexes' nucleation rate (Eq. 9) into the model. For our comparison, we consider the experimental data gained in our measurements with LACIS as well as data from earlier experiments (Maki et al., 1974; Yankofsky et al., 1981; Lindow et al., 1982; Wood et al., 2002). Results are shown in Fig. 8, depicting ice fractions as a function of temperature.

First, considering the results found at LACIS, the CHESS model reproduces the ice fractions measured (blue and black squares) for the $650 \mathrm{~nm}(\lambda=0.228$, blue curve $)$ and $800 \mathrm{~nm}$ $(\lambda=0.536$, black curve) particles very well. Both, slope of the ice fraction curve, and ice fraction at saturation, are nicely reproduced by the model. However, this is not surprising, as the model parameters ( $\lambda$ and $J_{\text {het }}$ ) were derived from this data. For the polydisperse measurements performed at LACIS (light blue square), $\lambda$ has a value of 0.0055 . The CHESS model (light blue line) predicts an increase of the ice fraction from $5 \times 10^{-4}$ to its maximum value for temperatures ranging from $-8.5^{\circ} \mathrm{C}$ to $-10^{\circ} \mathrm{C}$. The $\lambda$ value for this polydisperse experiment is quite low because most of the particles generated from the Snomax ${ }^{\mathrm{TM}}$ solution/suspension do not contain an INA protein complex initiating ice nucleation, as already shown in Fig. 6.

Next, we apply the CHESS model to other experimental data. Thereto, we use again the above-determined and parameterised heterogeneous ice nucleation rate (Eq. 9). With this, $\lambda$ and the ice nucleation time $t$ are the only free parameters in the model, which have to be adjusted for reproducing the experimental data. By doing so, we assume that in all considered experiments, ice nucleation is initiated by similar INA protein complexes, featuring similar nucleation rates (Eq. 9). Under this assumption, varying $\lambda$ and 
keeping $t$ constant, an increase in $\lambda$, which corresponds to an increase of the number of INA protein complexes present in the droplet population, will result in an increase of the saturation value of the ice fraction $\left(f_{\text {ice }}^{\star}\right)$. As a consequence, the $f_{\text {ice }}$ curve moves upwards while its slope does not change. This also results in an apparent increase of the temperature at which the ice fractions start to rise, or in other words, of the onset temperature of freezing. By changing $t$ and keeping $\lambda$ constant, the ice fraction curves are shifted similarly along the temperature axis, but again the slope of $f_{\text {ice }}$, and also the maximum ice fraction is not affected. If $\lambda$ is large enough, i.e., if $f_{\text {ice }}^{\star}$ is equal to one, increasing $\lambda$ or $t$ will both result in a shift of the $f_{\text {ice }}$ curve towards higher temperatures. In fact, in this range, there is a relation between $\lambda$ and $t$, implying that when analysing experimental data from that range with the CHESS model, a decrease in $\lambda$ corresponds to an increase in $t$, and vice versa. This allows for analysing experimental data even if the exact nucleation time is unknown as it is the case for the investigations presented below. Therefore, in the following considerations an ice nucleation time of $1 \mathrm{~s}$ can be assumed for convenience.

We start with ice fractions determined in the study by Wood et al. (2002) (green diamonds in Fig. 8), in which the immersion freezing of freely falling droplets containing particles smaller than $200 \mathrm{~nm}$ from a Snomax ${ }^{\mathrm{TM}}$ solution/suspension filtrate was analysed. By means of the CHESS model an average number of INA protein complexes of $\lambda \approx 28.6$ (green line) is calculated. The slopes of the measured and predicted $f_{\text {ice }}$ curves agree very well. From this, it follows that in Wood et al. (2002) a temperature dependence of the heterogeneous ice nucleation rate similar to that in our study was found.

Interestingly, the CHESS model is able to reproduce the ice nucleation behaviour of $P$. syringae bacteria as well. This can be seen when looking at the results given in Yankofsky et al. (1981), who analysed the freezing behaviour of droplets with multiple immersed $P$. syringae cells (stationary phase of bacteria growth). For a cell concentration of about $1-4 \times 10^{9}$ cells ml $^{-1}$, corresponding to about $5 \times 10^{6}-2 \times 10^{7}$ cells drop ${ }^{-1}$ (dark brown hexagons), the slopes of measured and calculated ice fraction curves also agree with a reasonably small deviation, presumably within the measurement uncertainties. In this case, the CHESS model predicts an average number of INA protein complexes of 170.1 , i.e., a number much smaller than the given bacteria cell concentration per droplet. This indicates that only a minor fraction of the bacteria was ice active.

Unfortunately in many studies (Orser et al., 1985; Wolber et al., 1986; Lindow et al., 1989; Attard et al., 2012), the concentrations of bacterial cells in the examined droplets are not reported, and therefore the cumulative ice nuclei concentrations given in these studies cannot be converted to ice fractions $\left(f_{\text {ice }}\right)$, and hence they cannot be included in our comparison.
However, Lindow et al. (1982) directly reported frozen fractions. They analysed the freezing of $P$. syringae cells as function of temperature and cell concentration. For a lower $P$. syringae cell concentration $\left(3.5 \times 10^{4}\right.$ cells ml $^{-1}$ corresponding to about $1.2 \times 10^{3}$ cells drop $^{-1}$, dark green triangle) the model predicts a $\lambda$ value of about $2.8 \times 10^{5}$ (dark green line) and for a higher cell concentration $\left(3.5 \times 10^{7}\right.$ cells ml ${ }^{-1}$ corresponding to about $1.2 \times 10^{6}$ cells drop ${ }^{-1}$, dark cyan triangle) a $\lambda$ value of about $2.3 \times 10^{6}$ (dark cyan line), respectively. The shift of the ice fraction curve towards higher temperatures with increasing cell concentration is nicely reproduced. However, agreement between $\lambda$ values and cell concentrations is only qualitative. Possible reasons for that are, that the fraction of cells being ice nucleation active was different for the different experiments, or that the number of cells per droplet was so large that class I and II ice nucleation activities started to become important. Additionally, as stated above, we use an ice nucleation time of $1 \mathrm{~s}$ to determine the $\lambda$ values. For the drop freezing method however, ice nucleation times are usually much longer (on the order of minutes). But as nucleation times are usually not reported, a quantitative comparison of $\lambda$ values with cell number per droplet cannot be obtained. Therefore, further research is needed to explore the relation between the number of INA protein complexes and the number of cells present, especially in the range of high cell concentrations.

Another study dealing with the immersion freezing of droplets containing multiple $P$. syringae bacteria cells (red and purple dots) is described in Maki et al. (1974). In this publication, ice fractions at two different temperatures are given for different samples with different but unknown cell concentrations. A deviation between the observed and modelled temperature dependencies of the ice fractions could be inferred from the comparison, however considering the sparseness of the experimental data, a meaningful comparison is difficult.

Generally, applying the CHESS model together with the nucleation rate expression for INA protein complexes as suggested in this work, we observe an overall good agreement between the calculated and measured slopes of the ice fraction curves, and a shift of the ice fraction curves to higher temperatures (higher onset temperatures) with an increasing number of INA protein complexes and/or cells. This shift of the ice fraction curves to higher freezing temperatures with increasing number of INA protein complexes/bacteria cells was observed in e.g., Ward and DeMott (1989) and Cochet and Widehem (2000) as well.

Summarising the results presented above, it can be stated that the CHESS model, together with the heterogeneous ice nucleation rate expression for single class III INA protein complexes, is capable of describing the ice nucleation behaviour observed in various experiments for both Snomax ${ }^{\mathrm{TM}}$ and $P$. syringae bacteria. This implies that the heterogeneous ice nucleation rate, and its temperature dependence, seem to be very similar, regardless of whether the INA protein 
complex causing the ice nucleation ability is attached to the outer cell membrane of intact bacteria or to cell membrane fragments. In this context, it is worth mentioning again that in our experiments, we mainly investigated class III nucleation activity while some of the experiments shown in the above comparison may feature cell concentrations which make the presence of class I and II ice nucleation activity likely. The good agreement between the measured and calculated ice fractions then suggests that the temperature dependence of the nucleation rates is similar, regardless of which class of activity is considered. However, this is highly speculative and requires further investigations. Furthermore, it can be stated that the temperature range in which heterogeneous droplet freezing occurs, and the fraction of droplets able to freeze, both depend on the actual number of INA protein complexes present in the droplet ensemble. Consequently, ice fractions and onset temperatures may not be the proper parameters to quantify ice nucleation behaviour. Finally, the fact that we are able to consistently describe a variety of different experiments with the same nucleation rate indicates that this nucleation rate is a suitable property for quantifying ice nucleation behaviour. It also suggests that possible artifacts suspected to occur in connection with the drop freezing method introduced by Vali (1971), as mentioned in the Introduction, are of minor importance, at least for substances which induce freezing at such high temperatures as $P$. syringae.

\section{Summary and conclusions}

At LACIS, the immersion freezing behaviour of monodisperse particles generated from a Snomax ${ }^{\mathrm{TM}}$ solution/suspension was investigated by measuring ice fractions as a function of temperature in the range between $-6.6^{\circ} \mathrm{C}$ and $-38^{\circ} \mathrm{C}$. Snomax ${ }^{\mathrm{TM}}$ is an industrial product applied for artificial snow production and contains Pseudomonas syringae bacteria which have long been used as model organism for atmospheric relevant INA bacteria. The ice nucleation activity of such bacteria is controlled by INA protein complexes in the outer membrane of the bacterial cell wall.

From the facts, that (a) the measured ice fraction curves feature a saturation behaviour, suggesting that not all generated particles contained an ice nucleus, (b) the number of particles/droplets containing IN was found to be a function of particle volume, and (c) already $100 \mathrm{~nm}$ particles exhibited a detectable ice nucleation ability, we concluded that the ice nucleating entity we were examining in our experiments was an INA protein complex attached to either intact cells or fragments of outer membrane of the bacterial cell wall. Both, statistical analysis and temperature range in which freezing was observed, are indicative for the examined INA protein complexes featuring a class III ice nucleation activity. For particles in the size range where intact bacteria are to be expected $(>600 \mathrm{~nm})$, we found that less than $50 \%$ of the particles were ice nucleation active despite the low temperatures (down to $-38^{\circ} \mathrm{C}$ ), indicating that maybe only half of the bacteria were able to nucleate ice, i.e., were carrying an INA protein complex. This finding supports data available in the literature suggesting that the majority of $P$. syringae cells have none, one or only little more than one ice forming site on their surface (e.g., Orser et al., 1985; Wolber et al., 1986; Lindow et al., 1989; Attard et al., 2012).

In order to derive the heterogeneous ice nucleation rate of the INA protein complexes, a simple model, the CHESS model, was developed. The CHESS model is based on the assumptions that the INA protein complexes are Poisson distributed over a droplet ensemble, and that the heterogeneous ice nucleation on similar INA protein complexes is a stochastic process. Under these assumptions, the average nucleation rate for class III INA protein complexes was determined and parameterised as function of temperature.

Uitilising the parameterised nucleation rate implemented into the CHESS model, we compared predictions from the model to other experimental data. In these investigations, the number of INA protein complexes present in the droplets, and the ice nucleation time were the only free parameters.

We found that:

- The heterogeneous ice nucleation rate expression quantifying the ice nucleation behaviour of single INA protein complexes is capable of describing the ice nucleation behaviour observed in various experiments for both, Snomax ${ }^{\mathrm{TM}}$ and $P$. syringae bacteria.

- The ice nucleation rate, and its temperature dependence, seem to be very similar regardless of whether the INA protein complexes are attached to the outer membrane of intact bacteria or cell membrane fragments.

- The temperature range in which heterogeneous droplet freezing occurs, and the fraction of droplets being able to freeze, both depend on the average number of INA protein complexes present in the droplet ensemble.

- Possible artifacts suspected to occur in connection with the drop freezing method introduced by Vali (1971) are of minor importance, at least for substances such as $P$. syringae.

The last two statements require additional remarks. It should be noted that in case of single ice nucleation entities such as INA protein complexes, which are not necessarily attached to a solid particle, it is the average number of entities in the droplet population, and the entities' nucleation rate, which control the freezing behaviour of the droplet population. Quantities such as active site density (DeMott, 1995) are not suitable in this context.

The last statement in the bulleted list is based on the fact that our LACIS measurements and the droplet freezing method yield similar results concerning the nucleation rate of the INA protein complexes. This implies that in the droplet 
freezing method according to Vali (1971), possible interferences such as nucleation by substrates seem to be of minor importance, at least when examining substances which induce freezing at temperatures as high as $P$. syringae. Furthermore, it should be noted that when applying the droplet freezing method, reporting the specific concentrations used, sizes of the examined droplets, the cooling rates applied, and time of freezing observed, as well as the frozen fractions determined, would be very valuable. Presenting only the final information about number of ice nuclei per cell, as done, for example, in a lot of the above mentioned publications, limits the possibility for further use of the data, e.g., for calculating the parameters described in this study.

At the end, some additional remarks, suggestions, and hypotheses, based on the results gained in the present study: firstly, it should be noted that the presented nucleation rate on its own already allows for the dynamic simulation of bacteria induced heterogeneous ice nucleation in cloud or larger scale models. Here the nucleation rate could e.g., represent the source term in the differential equation describing the time evolution of the number concentration of frozen droplets. Alternatively, CHESS model and nucleation rate together could be used for parameterising bacterial ice nucleation in larger scale models. This approach allows for the determination of frozen droplet fractions for a given temperature and time, without solving a differential equation. In addition to temperature and time, both approaches require information concerning the number of INA protein complexes present in the droplet population. This number could be determined having particle number and mass concentrations as model variables, and e.g., number of INA protein complexes per particle mass as a parameter. However, it has to be noted that the number of INA protein complexes per particle mass is currently a parameter that is difficult to quantify and which needs to be constrained by atmospheric measurements. As a first approximation the average number of ice nucleating bacteria could be used. However, even data concerning the number of ice nucleating bacteria per droplet or volume of precipitation is still sparse as already mentioned in the Introduction. Looking into densities of total bacterial IN larger than $0.2 \mu \mathrm{m}$ in precipitation, Christner et al. (2008) found between 4 and 120 bacterial IN per litre of precipitation. Also in precipitation, two studies have found that between $2 \%$ and $19 \%$ of bacteria, which could be cultivated under laboratory conditions, were INA (Stephanie and Waturangi, 2011; ŠantlTemkiv et al., 2013). Joly et al. (2013) studied INA bacteria in cloud water and could estimate that clouds over Puy de Dôme contain between around 0 and 500 INA bacteria per ml of cloud water, which corresponds to a single INA cell in every $10^{7}-10^{15}$ of cloud droplets (assuming a diameter of $10 \mu \mathrm{m}$ ). However, all these studies, except Christner et al. (2008), only investigated the fraction of INA bacteria that was alive and could grow under laboratory conditions. Thus, the actual atmospheric densities of bacterial IN are still largely unknown and the currently accepted densities may only represent the lower bound as will be discussed below.

The application of the CHESS model is not limited to INA protein complexes only. In fact, it could be applied for other IN types, e.g., ice nucleation active protein complexes from other bacteria or macro-molecules from pollen (Pummer et al., 2012; Augustin et al., 2012), under the condition that the IN considered as one type all feature similar ice nucleation properties and that these IN are Poisson distributed over the droplet population.

Concerning the relevance of INA protein complexes for atmospheric ice nucleation, it could be possible that INA protein complexes exist separately from intact bacterial cells, even in nature, which then would imply (a) a decoupling of the protein complex and bacteria cell numbers, and (b) the possible enrichment of INA protein complexes on, e.g., plant surfaces or in soil. In this context, it is worth noting that Kleber et al. (2007) found INA protein complexes to be well preserved - and maybe accumulated - when being connected to mineral surfaces. Also Conen et al. (2011) found that organic matter consisting of remains of micro-organisms that took part in the degradation of plant debris is responsible for enhancing the ice nucleation of atmospheric mineral dust.

Such an enhancement of the ice nucleation ability of mineral and soil dusts by bacterial IN could increase the importance of bacterial IN compared to the results presented in Hoose et al. (2010). However, this is highly speculative and needs further investigations.

Acknowledgements. This research project was performed in the framework of the German Research Foundation (DFG project WE 4722/1-1) research unit INUIT. Funding for T. Š.-T. was provided by The Danish National Research Foundation (Grant agreement no.: DNRF106) and the ASTERISK project (ASTERoseismic Investigations with SONG and Kepler) funded by the European Research Council (Grant agreement no.: 267864).

Edited by: B. Ervens

\section{References}

Ahern, H. E., Walsh, K. A., Hill, T. C. J., and Moffett, B. F.: Fluorescent pseudomonads isolated from Hebridean cloud and rain water produce biosurfactants but do not cause ice nucleation, Biogeosciences, 4, 115-124, doi:10.5194/bg-4-115-2007, 2007.

Amato, P., Parazols, M., Sancelme, M., Laj, P., Mailhot, G., and Delort, A. M.: Microorganisms isolated from the water phase of tropospheric clouds at the Puy de Dôme: major groups and growth abilities at low temperatures, Fems Microbiol. Ecol., 59, 242-254, 2007.

Ansmann, A., Tesche, M., Seifert, P., Althausen, D., Engelmann, R., Fruntke, J., Wandinger, U., Mattis, I., and Müller, D.: Evolution of the ice phase in tropical altocumulus: SAMUM lidar observations over Cape Verde, J. Geophys. Res.-Atmos., 114, D17208, doi:10.1029/2008JD011659, 2009. 
Attard, E., Yang, H., Delort, A.-M., Amato, P., Pöschl, U., Glaux, C., Koop, T., and Morris, C. E.: Effects of atmospheric conditions on ice nucleation activity of Pseudomonas, Atmos. Chem. Phys., 12, 10667-10677, doi:10.5194/acp-1210667-2012, 2012.

Augustin, S., Hartmann, S., Pummer, B., Grothe, H., Niedermeier, D., Clauss, T., Voigtländer, J., Tomsche, L, Wex, H. and Stratmann, F.: Immersion freezing of birch pollen washing water, Atmos. Chem. Phys. Discuss., 12, 32911-32943, doi:10.5194/acpd-12-32911-2012, 2012.

Burrows, S. M., Elbert, W., Lawrence, M. G., and Pöschl, U.: Bacteria in the global atmosphere - Part 1: Review and synthesis of literature data for different ecosystems, Atmos. Chem. Phys., 9, 9263-9280, doi:10.5194/acp-9-9263-2009, 2009.

Christner, B. C., Morris, C. E., Foreman, C. M., Cai, R. M. and Sands, D. C.: Ubiquity of biological ice nucleators in snowfall, Science, 319, 1214-1214, 2008.

Clauss, T., Kiselev, A., Hartmann, S., Augustin, S., Pfeifer, S., Niedermeier, D., Wex, H., and Stratmann, F.: Application of linear polarized light for the discrimination of frozen and liquid droplets in ice nucleation experiments, Atmos. Meas. Tech., 6, 1041-1052, doi:10.5194/amt-6-1041-2013, 2013.

Cochet, N. and Widehem, P.: Ice crystallization by Pseudomonas syringae, Appl. Microbiol. Biotech., 54, 153-161, doi:10.1007/s002530000377, 2000.

Conen, F., Morris, C. E., Leifeld, J., Yakutin, M. V., and Alewell, C.: Biological residues define the ice nucleation properties of soil dust, Atmos. Chem. Phys., 11, 9643-9648, doi:10.5194/acp-119643-2011, 2011.

DeLeon-Rodriguez, N., Lathem, T. L., Rodriguez-Rojas, L. M., Barazesh, J. M., Anderson, B. E., Beyersdorf, A. J., Ziemba, L. D., Bergin, M., Nenes, A., and Konstantinidis, K. T.: Microbiome of the upper troposphere: Species composition and prevalence, effects of tropical storms, and atmospheric implications, Proc. Natl. Acad. Sci., 110, 2575-2580, doi:10.1073/pnas.1212089110, 2013.

DeMott, P. J.: Quantitative descriptions of ice formation mechanisms of silver iodide-type aerosols. Atmos. Res., 38, 63-99, 1995.

DeMott, P. J., Sassen, K., Poellot, M. R., Baumgardner, D., Rogers, D. C., Brooks, S. D., Prenni, A. J. and Kreidenweis, S. M.: African dust aerosols as atmospheric ice nuclei. Geophys. Res. Lett., 30, 1732, doi:10.1029/2003GL017410, 2003.

Després, V. R., Huffman, J. A., Burrows, S. M., Hoose, C., Safatov, A. S., Buryak, G., Fröhlich-Nowoisky, J., Elbert, W., Andreae, M. O., Pöschl, U. and Jaenicke, R.: Primary biological aerosol particles in the atmosphere: a review, Tellus B, 64, 15598, doi:10.3402/tellusb.v64i0.15598, 2012.

Fuzzi, S., Mandrioli, P., and Perfetto, A.: Fog droplets - An atmospheric source of secondary biological aerosol particles, Atmos. Environ., 31, 287-290, 1997.

Garnham, C. P., Campbell, R. L., Walker, V. K. and Davies, P. L.: Novel dimeric beta-helical model of an ice nucleation protein with bridged active sites, BMC Struct. Biol., 11, doi:10.1186/1472-6807-11-36, 2011.

Green, R. L. and Warren, G. J.: Physical and functional repetition in an bacterial ice nucleation gene, Nature, 317, 645-648, 1985.
Govindarajan, A. G. and Lindow, S. E.: Size of bacterial icenucleation sites measured in-situ by radiation inactivation analysis, Proc. Nat. Acad. Sci. USA, 85, 1334-1338, 1988.

Hartmann, S., Niedermeier, D., Voigtländer, J., Clauss, T., Shaw, R. A., Wex, H., Kiselev, A., and Stratmann, F.: Homogeneous and heterogeneous ice nucleation at LACIS: operating principle and theoretical studies, Atmos. Chem. Phys., 11, 17531767, doi:10.5194/acp-11-1753-2011, 2011.

Hoose, C., Kristjánsson, J. E. and Burrows, S. M.: How important is biological ice nucleation in clouds on a global scale?, Environ. Res. Lett., 5, 024009, doi:10.1088/1748-9326/5/2/024009, 2010.

Hoose, C. and Möhler, O.: Heterogeneous ice nucleation on atmospheric aerosols: A review of results from laboratory experiments, Atmos. Chem. Phys., 12, 9817-9854, doi:10.5194/acp12-9817-2012, 2012.

Joly, M., Attard, E., Sancelme, M., Deguillaume, L., Guilbaud, C., Morris, C. E., Amato, P., and Delort, A.-M.: Ice nucleation activity of bacteria isolated from cloud water, Atmos. Environ., 70, 392-400, doi:10.1016/j.atmosenv.2013.01.027, 2013.

Kamphus, M., Ettner-Mahl, M., Klimach, T., Drewnick, F., Keller, L., Cziczo, D. J., Mertes, S., Borrmann, S., and Curtius, J.: Chemical composition of ambient aerosol, ice residues and cloud droplet residues in mixed-phase clouds: single particle analysis during the Cloud and Aerosol Characterization Experiment (CLACE 6), Atmos. Chem. Phys., 10, 8077-8095, doi:10.5194/acp-10-8077-2010, 2010.

Kanitz, T., Seifert, P., Ansmann, A., Engelmann, R., Althausen, D., Casiccia, C., and Rohwer, E. G.: Contrasting the impact of aerosols at northern and southern midlatitudes on heterogeneous ice formation, Geophys. Res. Lett., 38, L17802, doi:10.1029/2011GL048532, 2011.

Kawahara, H.: The structures and functions of ice crystalcontrolling proteins from bacteria, J. Biosci. Bioeng., 94, 492496, 2002.

Kleber, M., Sollins, P. and Sutton, R.: A conceptual model of organo-mineral interactions in soils: self-assembly of organic molecular fragments into zonal structures on mineral surfaces, Biogeochemistry, 85, 9-24, 2007.

Knutson, E. O. and Whitby, K. T.: Aerosol classification by electric mobility: Apparatus, theory and applications, J. Aerosol Sci., 6, 443-451, 1975.

Levin, Z. and Yankofsky, S. A.: Contact Versus Immersion Freezing Of Freely Suspended Droplets By Bacterial Ice Nuclei, J. Climate Appl. Meteorol., 22, 1964-1966, 1983.

Lindow, S. E., Arny, D. C., and Upper, C. D.: Bacterial ice nucleation - a factor in frost injury to plants, Plant Physiol., 70, 10841089, 1982.

Lindow, S. E., Lahue, E., Govindarajan, A. G., Panopoulos, N. J., and Gies, D.: Localization of ice nuleation activity and the iceC gene product in Pseudomonas syringae and Escherichia-coli, Mol. Plant Microbe In., 2, 262-272, 1989.

Lohmann, U.: Aerosol effects on clouds and climate, Space Sci. Rev., 125, 129-137, 2006.

Maki, L. R. and Willoughby, K. J.: Bacteria as biogenic sources of freezing nuclei, J. Appl. Meteorol., 17, 1049-1053, 1978.

Maki, L. R., Galyan, E. L., Chang-Chien, M.-M., and Caldwell, D. R.: Ice nucleation induced by Pseudomonas syringae, Appl. Microbiol., 28, 456-459, 1974. 
Möhler, O., Georgakopoulos, D. G., Morris, C. E., Benz, S., Ebert, V., Hunsmann, S., Saathoff, H., Schnaiter, M., and Wagner, R.: Heterogeneous ice nucleation activity of bacteria: new laboratory experiments at simulated cloud conditions, Biogeosciences, 5, 1425-1435, doi:10.5194/bg-5-1425-2008, 2008.

Monteil, C. L., Guilbaud, C., Glaux, C., Lafolie, F., Soubeyrand, S., and Morris, C. E.: Emigration of the plant pathogen Pseudomonas syringae from leaf litter contributes to its population dynamics in alpine snowpack, Environ. Microbiol., 14, 20992112, 2012.

Morris, C. E. and Sands, D. C.: From Grains to Rain: the link between landscape, airborne microorganisms and climate processes, e-book, accessed 26 April 2012, http://bioice.wordpress. $\mathrm{com} /, 2012$.

Morris, C. E., Georgakopoulos, D. G., and Sands, D. C.: Ice nucleation active bacteria and their potential role in precipitation. J. Phys. IV, 121, 87-103, 2004.

Morris, C. E., Sands, D. C., Vinatzer, B. A., Glaux, C., Guilbaud, C., Buffiere, A., Yan, S. C., Dominguez, H., and Thompson, B. M.: The life history of the plant pathogen Pseudomonas syringae is linked to the water cycle, ISME J., 2, 321-334, 2008.

Mueller, G. M., Wolber, P. K., and Warren, G. J.: Clustering of ice nucleation protein correlates with ice nucleation activity, Cryobiology, 27, 416-422, 1990.

Murray, B. J., O’Sullivan, D., Atkinson, J. D., and Webb, M. E.: Ice nucleation by particles immersed in supercooled cloud droplets. Chem. Soc. Rev., 41, 6519-6554, 2012.

Niedermeier, D., Hartmann, S., Shaw, R. A., Covert, D., Mentel, T. F., Schneider, J., Poulain, L., Reitz, P., Spindler, C., Clauss, T., Kiselev, A., Hallbauer, E., Wex, H., Mildenberger, K., and Stratmann, F.: Heterogeneous freezing of droplets with immersed mineral dust particles - measurements and parameterization, Atmos. Chem. Phys., 10, 3601-3614, doi:10.5194/acp-103601-2010, 2010.

Niedermeier, D., Shaw, R. A., Hartmann, S., Wex, H., Clauss, T., Voigtländer, J., and Stratmann, F.: Heterogeneous ice nucleation: exploring the transition from stochastic to singular freezing behavior, Atmos. Chem. and Phys., 11, 8767-8775, doi:10.5194/acp-11-8767-2011, 2011a.

Niedermeier, D., Hartmann, S., Clauss, T., Wex, H., Kiselev, A., Sullivan, R. C., DeMott, P. J., Petters, M. D., Reitz, P., Schneider, J., Mikhailov, E., Sierau, B., Stetzer, O., Reimann, B., Bundke, U., Shaw, R. A., Buchholz, A., Mentel, T. F., and Stratmann, F.: Experimental study of the role of physicochemical surface processing on the IN ability of mineral dust particles, Atmos. Chem. Phys., 11, 11131-11144, doi:10.5194/acp11-11131-2011, 2011b.

Orser, C., Staskawicz, B. J., Panopoulos, N. J., Dahlbeck, D., and Lindow, S. E.: Cloning and expression of bacterial ice nucleation genes in Escherichia-coli, J. Bacteriol., 164, 359-366, 1985.

Pratt, K. A., DeMott, P. J., French, J. R., Wang, Z., Westphal, D. L., Heymsfield, A. J., Twohy, C. H., Prenni, A. J., and Prather, K. A.: In situ detection of biological particles in cloud ice-crystals, Nat. Geosci., 2, 397-400, doi:10.1038/ngeo521, 2009.

Pummer, B. G., Bauer, H., Bernardi, J., Bleicher, S., and Grothe, H.: Suspendable macromolecules are responsible for ice nucleation activity of birch and conifer pollen. Atmos Chem Phys., 12, 2541-2550, doi:10.5194/acp-12-2541-2012, 2012.
Šantl-Temkiv, T., Finster, K., Sahyoun, M., Hartmann, S., Augustin, S., Stratmann, F., Wex, H., Clauss, T., Korsholm, U. S., Nielsen, N. W., Sorensen, J. H., and Karlson, U. G.: Airborne Pseudomonas sp. may increase the number of biological ice nuclei in the atmosphere by excreting ice nucleation active proteins, in preparation for Environ. Microbiol., 2013.

Schnell, R. C. and Vali, G.: Atmospheric ice nuclei from decomposing vegetation, Nature, 236, 163-165, 1972.

Schmid, D., Pridmore, D., Capitani, G., Battistutta, R., Neeser, J. R., and Jann, A.: Molecular organisation of the ice nucleation protein InaV from Pseudomonas syringae, Febs Lett., 414, 590594, 1997.

Seifert, P., Ansmann, A., Mattis, I., Wandinger, U., Tesche, M., Engelmann, R., Müller, D., Pérez, C., and Haustein, K.: Saharan dust and heterogeneous ice formation: eleven years of cloud observations at a Central European EARLINET site, J. Geophys Res.-Atmos., 115, D20201, doi:10.1029/2009JD013222, 2010.

Skirvin, R. M., Kohler, E., Steiner, H., Ayers, D., Laughnan, A., Norton, M. A., and Warmund, M.: The use of genetically engineered bacteria to control frost on strawberries and potatoes. Whatever happened to all of that research?, Sci. Hortic., 84, 179$189,2000$.

Southworth, M. W., Wolber, P. K., and Warren, G. J.: Nonlinear relationship between concentration and activity of a bacterial ice nucleation protein, J. Biol. Chem., 263, 15211-15216, 1988.

Stephanie, D. and Waturangi, E.: Distribution of ice nucleationactive (INA) bacteria from rain-water and rain, HAYATI Journal of Biosciences, 18, 108-112, 2011.

Stratmann, F., Kiselev, A., Wurzler, S., Wendisch, M., Heintzenberg, J., Charlson, R. J., Diehl, K., Wex, H., and Schmidt, S.: Laboratory studies and numerical simulations of cloud droplet formation under realistic supersaturation conditions, J. Atmos. Ocean. Tech., 21, 876-887, 2004.

Turner, M. A., Arellano, F., and Kozloff, L. M.: Three separate classes of bacterial ice nucleation structures, J. Bacteriol., 172, 2521-2526, 1990.

Turner, M. A., Arellano, F., and Kozloff, L. M.: Components of ice nucleation structures of bacteria, J. Bacteriol., 173, 6515-6527, 1991.

Twohy, C. H. and Poellot, M. R.: Chemical characteristics of ice residual nuclei in anvil cirrus clouds: evidence for homogeneous and heterogeneous ice formation, Atmos. Chem. Phys., 5, 22892297, doi:10.5194/acp-5-2289-2005, 2005.

Vali, G.: Quantitative Evaluation Of Experimental Results On Heterogeneous Freezing Nucleation Of Supercooled Liquids, J. Atmos. Sci., 28, 402-409, 1971.

Vali, G., Christensen, M., Fresh, R. W., Galyan, E. L., Maki, L. R., and Schnell, R. C.: Biogenic ice nuclei. Part II: Bacterial sources, J. Atmos. Sci., 33, 1565-1570, 1976.

van Overbeek, L. S., Nijhuis, E. H. M., Koenraadt, H., Visser, J., and van Kruistum, G.: The role of crop waste and soil in Pseudomonas syringae pathovar porri infection of leek (Allium porrum), Appl. Soil Ecol., 46, 457-463, 2010.

Ward, P. J. and DeMott, P. J.: Preliminary Experimental Evaluation of Snomax ${ }^{\mathrm{TM}}$ Snow Inducer, Pseudomonas syringae, as an Artificial Ice Nucleus, J. Weather Mod., 21, 9-13, 1989.

Warren, G. and Wolber, P.: Molecular aspects of microbial ice nucleation, Mol. Microbiol., 5, 239-243, 1991. 
Warren, G. J. and Wolber, P. K.: Heterogeneous ice nucleation by bacteria, Cryo. Lett., 8, 204-217, 1987.

Wilck, M., Stratmann, F., and Whitby, E.: A fine particle model for fluent: Description and application, in: Proc. Sixth Int. Aerosol Conf., 1269-1270, Chinese Association for Aerosol Research in Taiwan/International Aerosol Research Assembly, Taipei, Taiwan, 2002.

Wolber, P. K., Deininger, C. A., Southworth, M. W., Vandekerckhove, J., Vanmontagu, M., and Warren, G. J.: Identification and purification of a bacterial ice-nucleation protein, P. Natl. A. Sci. USA, 83, 7256-7260, 1986.
Wood, S. E., Baker, M. B., and Swanson, B. D.: Instrument for studies of homogeneous and heterogeneous ice nucleation in freefalling supercooled water droplets, Rev. Sci. Inst., 73, 39883996, 2002.

Yankofsky, S. A., Levin, Z., Bertold, T., and Sandlerman, N.: Some basic characteristics of bacterial freezing nuclei, J. Appl. Meteorol., 20, 1013-1019, 1981. 